\title{
Female Presence on Corporate Boards: A Multi-Country Study of Environmental Context
}

Siri Terjesen
Val Singh

\begin{abstract}
A growing body of ethics research investigates gender diversity and governance on corporate boards, at individual and firm levels, in single country studies. In this study, we explore the environmental context of female representation on corporate boards of directors, using data from 43 countries. We suggest that women's representation on corporate boards may be shaped by the larger environment, including the social, political and economic structures of individual countries. We use logit regression to conduct our analysis. Our results indicate that countries with higher representation of women on boards are more likely to have women in senior management and more equal ratios of male to female pay. However, we find that countries with a longer tradition of women's political representation are less likely to have high levels of female board representation.
\end{abstract}

KEY WORDS: corporate boards, environmental context, female directors, gender, multi-country, pay gap, political representation

ABBREVIATIONS: EC: European Commission; EU: European Union; FTSE: Financial Times Stock Exchange; ILO: International Labor Organization; OECD: Organization for Economic Cooperation and Development; UK: United Kingdom; UNDP: United Nations Development Programme; USA: United States; WEU: Women and Equality Unit

\section{Introduction}

Although women are joining the labour force in increasing numbers around the world (Economist, 2006), they remain proportionately under-represented in the top tiers of management (ILO, 2004). In particular, the lack of female representation on corporate boards of directors is a global phenomenon. Women comprise less than $15 \%$ of corporate board members in the USA, UK, Canada, Australia and many European countries, but as low as $0.2 \%$ in some Asian countries. A growing body of research in business ethics explores gender diversity and corporate governance, focusing on micro-level studies of the characteristics of female board members, their boards and firms and the effects of gender diversity. Our research extends the extant person- and situation-centred discussions to consider environmental explanations.

Gender diversity in management is said to provide a number of benefits, including new ideas and improved communication (Milliken and Martins, 1996), insights on female market segmentation (Daily et al., 1999) and transformational management style (Rosener, 1990). These competencies are particularly critical in a global world, where women also play active roles as entrepreneurs, managers and consumers (Economist, 2006). Adler (1997) emphasised the importance of having women as well as men in the global talent pool in order to identify the next generation of leaders in the global society. Wise global leaders need the ability to work interactively and sensitively with leaders from other cultures, and Adler highlights how some women global leaders use influence and inspiration, rather than command and control to achieve their goals.

Furthermore, female board members represent career opportunities for potential female employees (Bilimoria, 2006), inspire women employees to senior management roles (Bilimoria and Wheeler, 2000) and often engage in networking and mentoring of women through corporate networks. These positive spillovers may extend outside the firm. For example, law firms whose key clients have women on their boards are more likely to promote 
women (Beckman and Phillips, 2005). While the importance of women to corporate boards has been long acknowledged (Burke, 1997; Bilimoria and Wheeler, 2000), females have made only modest gains in terms of directorships on corporate boards (Arken et al., 2004; Daily et al., 1999).

To date, research on female board representation has explored individual and firm factors, mostly in single country studies. An extensive body of person-centred research explores individual characteristics of board appointees including education, work experience (e.g. Burgess and Tharenou, 2002; Hillman et al., 2002; Kesner, 1988) and social networks (Burke, 1997). Firm-centred research has explored corporate governance practice, presence of senior women managers and barriers (Coffey and Wang, 1998; Fryxell and Lerner, 1989; Oakley, 2000) and the effect of gender diversity on firm philanthropy (Williams, 2003) and social responsiveness (Ibrahim and Angelidis, 1995). In addition to individual and firm level factors, there may be underlying conditions in the national environment that contribute to the representation of women on corporate boards. This article answers calls for research into board gender diversity (Daily et al., 1999), building on theoretical approaches (Bilimoria and Wheeler, 2000) and taking into account environmental context (Johnson et al., 1996).

In this research, we are interested in ascertaining what factors in the environment are associated with women's representation on the boards of the top echelon of firms by size and market power, including the USA's Fortune 100 and UK's FTSE100. We are interested in the presence of females in decisionmaking capacities in the highest stratum of these powerful multinational enterprises. We begin by putting forward three distinct hypotheses regarding the possible role of social, political and economic environment context. The results from our 43 country study are discussed, including implications for future research. We believe that this study is the first of its kind to explore the relationship between the macro-environment and the presence of women on corporate boards.

\section{Theoretical background}

We are interested in examining environmental factors that might affect the proportions of women on corporate boards. Studies at individual and firm levels assume that the labour market is open and fully competitive, and focus on the efforts of individuals and their organisations to adapt so that more women can achieve top positions. A review of the glass ceiling literature by Powell (1999) indicates that at the individual level, in the past, women were said to lack the necessary qualities such as ambition and confidence in comparison to men as well as leadership skills such as assertiveness and influencing behaviour. Women were also said to lack the relevant experience or education for leadership (Powell, 1999), although women now have higher academic qualifications on average than men (HESA, 2003). Situation-centred explanations include women's family responsibilities that hinder or are perceived to hinder their commitment to the organisation and their lack of involvement in corporate networks that provide access to powerful people. Other barriers are based in gendered social systems, where work has been designed by men for men, and where patriarchy defines work roles by gender, leading to direct discrimination and stereotyping. Structures such as recruitment and promotion systems operate in a gender-biased way, for instance in the assumption that career paths for leaders will be unbroken, thereby excluding women who take maternity leave or part-time work, or who relocate several times due to partners' career moves. Finally, interaction-centred explanations for the lack of women's advancement focus on the aggregated effect of interacting processes, such as women's reluctance to self-promote or actively manage their careers in organisations with informal promotion processes (Singh et al., 2002). This can lead to managerial assumptions that women are happy to continue with their present position, whilst male peers indicate much more strongly to the promotion gatekeepers their ambition, their career successes and their readiness for the next step. In such processes, women may self-limit their advancement unless managers are aware of gender differences and take steps, such as offering mentoring and advocacy, to address the situation. However, there are wider external structures and processes that also impact the enactment of women's careers, but these are under-researched.

In contrast to the explanations above, centred on the individual and the organisation, an environmental perspective takes an open systems view, and 
examines the rigidities of the wider structure which may produce constraints. Our primary contribution is the investigation of the role of the environment on the gender diversity of corporate boards. Our explanatory variables are derived from three forces in the macro-environment: social (the presence of women in senior management), political (women's historical role in government leadership positions) and economic (gender pay gap).

Female presence in senior management and legislature roles

The critical role of the labour markets is often neglected in extant individual and firm explanations for the representation of women on corporate board levels. Globally, women comprise the fastest growing section of the labour force, but are disproportionately over-represented in informal employment, unpaid work and undesirable sectors; and underrepresented in management roles (ILO, 2004). A variety of person-centred (e.g. socialisation process, personality traits) and situation-centred (e.g. nature of the work, group dynamics) explanations have been offered. For example, psychological processes such as homosocial reproduction were also thought to lead to women being disadvantaged by their gender during selection and promotion processes (Powell, 1999). Reports indicate that the proportion of female managers has improved over time in countries such as the USA and UK, but still lags behind men (USDOL, 2005; WEU, 2002).

The under-representation of senior women managers in private and public roles is a critical environmental context, as these managers constitute the population from which new board members are appointed. A study of new appointees to the UK's FTSE100 boards reported that half of the women had previous experience in financial institutions, a third had experience of senior positions in the public sector, and nearly a quarter had voluntary and charity organisations leadership experience, and many had sat on government advisory bodies, and boards of arts and other organisations (Singh et al., 2007). Research from Canada indicates that CEOs attribute the low number of women on boards due to their lack of such management qualifications (Burke, 1997). We expect that women who gain experience in legislative, management and other official roles will be considered for board appointments.

Hypothesis 1: Countries with higher levels of female representation in legislature, senior officials and managers are more likely to have women on their corporate boards.

Historical female presence in executive office

In this research, we wish to distinguish between women's 'pipeline' representation in lower bodies of the legislature (described above) and a second key element in the macro-environment: the historical involvement of women in the highest political echelon, the executive federal office. In many countries, female parliamentarians are a relatively recent phenomenon. For example, Singapore and Switzerland elected their first women into public office in 1963 and 1971, respectively. Other countries have a longer history of legislative representation. For example, in Europe, the first female parliamentarian was elected in Finland in 1907, and in Sweden only in 1922, whilst in the UK, it was in 1919 that Lady Astor took her seat at Westminster. Minority groups, including women, transition through five mobilisation processes, each with a threshold and period of stabilisation until the movement towards the next phase: legitimisation as citizens (males and females) prior to obtaining the vote; legitimisation as women entitled to suffrage (an additional threshold that men did not have to pass); incorporation, representation and executive power (Raaum, 2005).

However, women may have political representation, but not executive power, and unless female politicians reach a critical mass, change will come slowly, as demonstrated in the male-dominated ranks of most European parliaments. Raaum (2005) draws on token theory to explain this process, but highlights the arguments made by Dahlerup (1998) that the numerical representation theory does not take into account the continuing imbalance in male and female power bases within politics. For example, in the Nordic countries, it was not until the 1970s that all the parliaments (except Iceland) achieved at least 20\% female representation, but by 2004 , Sweden was far ahead of the others with 45\%. Indeed, in 1994 and still 
in $2005,50 \%$ of Swedish cabinet posts were held by women. It could be held that this represents executive power, the final stage of political mobilisation for Swedish women. Yet Sweden has never had a female prime minister, in contrast to Norway (1981) and Finland (2003), nor a female president, in contrast to Iceland (1980) and Finland (2000).

In her research on global women leaders, Adler (1997) describes the 'feminisation' of global leadership, a process by which women become disproportionately represented in customarily male occupations, and which results in the "spread of traits or qualities that are traditionally associated with [women]... to... people [and processes] not usually described that way" (Fondas, 1997, p. 258 in Adler, 1997, p. 184). The feminisation of leadership reflects a wider influence of interactive communication styles and character traits which might be expected to perpetuate in the corporate realms. Hence, we suspect the following:

Hypothesis 2a: Countries with a longer history of women in political office are more likely to have women on their corporate boards.

However, we could also argue that in countries where political power was achieved earlier, there is likely to be complacency in that gender inequality is no longer a burning issue. This contentment may lead to stagnation of effort for female representation in corporate spheres. Political activists are likely to have moved into other agendas, such as education and social welfare that attract more votes as they appeal to a wider range of the electorate than championing the cause of a few women directors. Thus, we suspect that countries with more recent female political representation may have more momentum in their change agenda and put more effort into increasing women's full participation in the business arena.

Hypothesis 2b: Countries with a shorter history of women in political office are more likely to have women on their corporate boards.

\section{The gender pay gap}

A final environmental factor concerning the lack of women on corporate boards may be the degree to which men and women receive unequal financial rewards for their work. Pay has symbolic value as a factor in career progression, and high pay represents individual achievement. In the career tournament model (Rosenbaum, 1989), important indicators of achievement including salary, age and level are used in the decision to promote individuals to the next round. Where men and women have career equality and hence equal access to the boardroom, there should be little difference in the indicators for promotability, including pay. Pay is an outcome of the employment exchange relationship, and women are generally weaker partners in a business and industrial world designed by males for male breadwinners. Women traditionally have not had the power to negotiate equal pay to men, remaining "others" in the work arena whose pay was, until recently, often seen as pin money to supplement male wages (Acker, 1990).

While the principle of equal pay for work of equal value has been endorsed by many countries, there is a persistent gender pay gap. Australia's 13\% pay gap, one of the lowest amongst OECD countries, is generally attributed to a highly regulated labour market, and early efforts to achieve pay equality on a comparable worth footing, given the highly segregated nature of the labour market (Eastough and Miller, 2004). Indeed, at the base level wages, there was no gender pay gap in Australia, due to minimum wage regulation. Australia's situation sharply contrasts with the non-regulated USA, where women pay a larger wages penalty than do their male peers for having low labour market skills and working in poorly paid sectors (Blau and Kahn, 2003). Even in the EU where the 1975 Equal Pay Directive made sex discrimination illegal in all aspects of pay, the average EU gender pay gap is $15 \%$ for hourly pay of full-time workers, and as high as $40 \%$ in the UK between women's part-time and men's full-time hourly pay. It is lowest in countries such as Bulgaria and Slovenia (Pollert, 2005; WEU, 2002). The EC's 2005 Employment Report suggests that some transitional economies' lower gender pay gap may be due, in part, to the increased need for skills predominantly held by women, particularly in the services sector. It may be that pay equality indicates equal work and equal opportunities for advancement, including corporate boards.

Hypothesis 3: Countries in which women earn a more equal share to men are more likely to have women on their corporate boards. 


\section{Data and methodology}

We compiled secondary data from a number of sources. The dependent variable, the percentage of women on corporate boards, is based on surveys of gender diversity on corporate boards, taken between 2003 and 2005. Our sources include the European Commission (2006), McKinsey (2005), Catalyst (2004), Center for Corporate Diversity (2004), Corporate Women Directors International (2004), Ding and Charoewong (2004) and Izraeli (2001). The following three independent variables are taken from the United Nations Development Programme Gender Empowerment Index (UNDP, 2006): (1) Percentage of females in the legislature, senior official and management positions; (2) Year that the first woman was elected to political office and (3) Ratio of earned income by females and males. We used logit regression to test our hypothesis.

\section{Results}

We begin by examining the percentage of women on corporate boards in the 43 countries. See Figure 1.

From Figure 1, large between-country differences are apparent, with board representation as low as $0.2 \%$ in Japan and as high as $22 \%$ in Slovenia. Next, we report the descriptive statistics in Table I. On average, women hold nearly $29 \%$ of senior leadership positions, however this varies from $6 \%$ in Turkey to $46 \%$ in the USA. The gender pay gap ranges from 35\% in Austria to 90\% in Switzerland. Finally, the year of the first woman elected to parliament ranges from 1907 (Finland) to 1992 (Croatia, Czech Republic and Slovenia). We did not identify any significant correlations among our variables, and thus do not have problems with multicollinearity.

Using logit regression, we report findings from our three hypothesis tests in Table II. As expected, we find that countries with a higher proportion of females in the legislature, senior official and management positions are significantly more likely $(p<0.001)$ to have higher representation of women on corporate boards. Hypothesis 1 is supported. Next, our results indicate that countries with a longer history of elected female officials are significantly less likely to have women on corporate boards. Hypothesis $2 \mathrm{a}$ is not supported, in fact, we find just the opposite, supporting Hypothesis $2 \mathrm{~b}$ : countries with a longer history of female political representation are significantly less likely $(p<0.001)$ to have women on their boards. Finally, our results indicate that countries in which women earn a more similar ratio of income to men are significantly more likely to have higher numbers of women on their corporate boards $(p<0.001)$. Hypothesis 3 is supported.

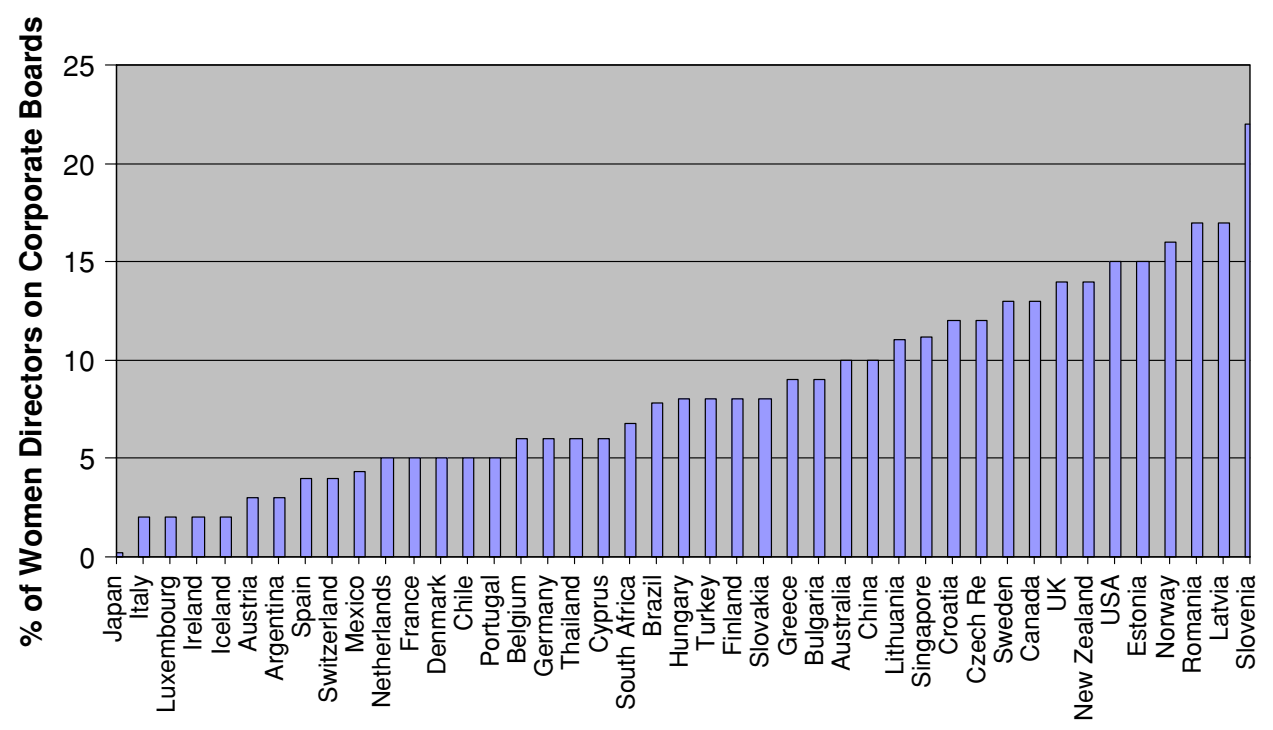

Figure 1. Percentage of women directors on corporate boards. 


\section{TABLE I}

Descriptive statistics and correlations among variables

\begin{tabular}{lcccc}
\hline Variable & Mean & Standard deviation & 1 & 2 \\
\hline 1. Female representation in legislature, senior officials and managers & 28.97 & 7.02 & & \\
2. Year that the first woman was elected to a federal political office & 1938.6 & 23.04 & -0.240 & \\
3. Wage gap: female to male earned income & 0.563 & 0.116 & 0.353 & -0.267
\end{tabular}

Note: No significant correlations among variables.

TABLE II

Percentage of women directors on corporate boards and environmental variables

\begin{tabular}{lc}
\hline & $\begin{array}{c}\text { Percent of women on } \\
\text { corporate boards } \\
\text { Standardized Co-eff. B } \\
\text { Significance }\end{array}$ \\
\hline Female representation in legislature, senior officials and managers (Hypothesis 1) & $0.288^{\star \star \star}$ \\
Year that the first woman was elected to a federal political office (Hypotheses 2a and 2b) & $0.441 \star \star \star$ \\
Wage gap: female to male earned income (Hypothesis 3) & $-0.215^{\star \star \star}$ \\
Overall $F$ & $8.48^{\star \star \star}$ \\
$R^{2}$ & 0.383 \\
Adjusted $R^{2}$ & 0.338 \\
\hline
\end{tabular}

$\star \star \star p<0.001$.

\section{Discussion}

Our results indicate the presence of several environmental variables that are associated with the representation of women on corporate boards: the percentage of senior women leaders, the gender pay gap and historical patterns of women's representation. We discuss each finding in turn. Consistent with findings that those appointing directors value women with prior corporate board experience (Mattis, 2000) and newly appointed female directors are likely to have previous experience on boards of non-profit and cultural organisations, as well as corporations (Bilimoria and Piderit, 1994), we find that countries with greater shares of senior women leaders will also have greater female representation on corporate boards.

Second, we find evidence that the pay gap is related to board gender diversity. Specifically, in countries where women and men earn similar amounts, there is a more equitable playing field and women are more likely to gain board positions.
Third, our findings belie some of the myths about environments in which females achieve directorships of publicly held firms. In particular, we find that higher numbers of female directorships are not associated with historical political elements. Environments with more recent political empowerment of women are in fact, more likely to have greater numbers of female directors. This finding includes countries such as Croatia, Czech Republic and Slovenia which elected women in 1992, and have 12, 12 and $22 \%$ female corporate board representation, respectively. These former Soviet-block economies are fast movers, outperforming countries such as Ireland, Denmark and the Netherlands which elected women as early as 1918 and have, respectively, 2, 5 and $5 \%$ female board representation. Another possible implication is that women have been pursuing careers in politics, rather than business. Indeed, there is anecdotal evidence of this in countries such as Norway and Sweden where women have historically dominated the public roles in government, but have 
had little involvement at senior levels in private and publicly listed firms.

Another possible explanation is that countries in which women have had more historical presence in parliament have become complacent, with a subsequent stagnation of equality promotion efforts to remedy the unequal playing field in the competition for business leadership positions. In addition, parliamentarians may choose to focus their efforts on inequalities for women in general, for example, better maternal health or better childcare support, that are likely to be sustained vote-catching policies. We see this today in the UK, where ministers are focused on helping women in the workplace, as evidenced by the 2006 Women and Work Commission, with policies and practices to help those women and men with family responsibilities. There are limited resources, and whilst there is voiced female ministerial support for increasing the representation of women on corporate boards, this issue is not of such general interest to citizens, nor is it continually on the agenda, in contrast to other social issues.

A further possibility is the presence of the "Queen Bee syndrome," that older women in powerful positions may resent their younger colleagues and sometimes deliberately hold them back. For example, some argue that the UK's former Prime Minister Margaret Thatcher did not seek to promote other women (Smith, 2000). Furthermore, it may be that early women in parliament tend to come largely from privileged backgrounds, and were more concerned about female suffrage rather than championing the cause for women in business leadership. Finally, the public sector may be more influenced by political will for change, whilst the private sector is resistant, even in Scandinavia. A combination of factors may be important.

We acknowledge several limitations of our study. First, as there is no directly comparable cross-country measure of the percentage of women directors on corporate boards available, we gathered our data from a variety of sources. The European Commission (EU, 2006) uses data from the top 50 companies in each country, however other countries' data is based on a slightly smaller (e.g. Lithuania) or larger (e.g. US) sample of firms. Second, we do not control for the countries' average size of boards, size of companies and industry dominance. Several single-country studies have shown that firms with larger market capitalisation are more likely to have more directors on their boards and a higher proportion of female directors, however some countries set a limit to the number of directors on their boards.

\section{Conclusions}

We set out to investigate the role of some national environmental factors in relation to the proportions of women on corporate boards. Our contribution is the introduction of national environmental context to complement the person-centred and organisationcentred explanations of the glass ceiling. We have identified three significant factors relating the social, political and economic environments in these 43 countries to the proportion of women on boards. The countries where more women have made it to the boardroom are those with women in senior management levels, smaller gender pay gaps and a shorter period of women's political representation.

Around the world, governments have become more aware of the correlation between sex equality, particularly in the labour market, and economic growth and prosperity, through their labour and also their role in raising healthier, more highly educated children (Economist, 2006). Many governments actively monitor the implementation and effectiveness of diversity policies and practices, and use robust research results to design interventions. Gender diversity research on corporate boards is an important tool, not only for making an academic contribution, but also for providing the basis for change to a more equitable gender representation at the decision-making levels of the corporate world. According to the business case, gender diversity at leadership level offers a strategic advantage in meeting the challenge of globalisation as women can bring their diversity, cross-cultural awareness and transformational leadership skills to their boards (Adler, 1997).

In the course of our research, we have identified a number of trends that are important to watch. First, we believe that the changing demographic profile of the workforce in Europe, Asia and the Americas may result in more women on the board. For example, in the UK labour force, women are expected to outnumber men by 2018 (WEU, 2002). Second, corporate governance scandals such as Enron, Worldcom and Parmalat have prompted a new set of regulations (e.g. Sarbanes-Oxley Act; Combined Code) concerning the structures and processes of 
company boards and the roles and responsibilities of independent directors. Subsequent reports recommend increasing board diversity, including gender representation.

The increasing proportion of women in parliaments, as demonstrated in the Nordic countries, should facilitate executive power attention to issues of gender inequality not only in terms of political representation, as is the case in more than 40 countries where quotas for women have recently been introduced (Dahlerup and Freidenvall, 2005), but also in the workplace, including the presence of women on corporate boards. Norway led in this regard, with action taken in 2002 to introduce legislation for a $40 \%$ female representation on corporate boards within 3 years. The deadline has now been extended to 2008, with severe penalties for noncompliance, including termination of the company. Sweden followed suit in May 2006, setting quotas and fines of 15,000 euros. The Finnish EU Presidency held a meeting in October 2006 to discuss European level strategies to increase women's share of top-level corporate directorships. Similar quota measures are now under serious consideration in Spain, Finland and France, and several other countries are watching the outcomes with great interest.

This study suggests a number of avenues for future research, including the extension to more countries and the role of other environmental variables. Longitudinal data would enable an investigation, over time, of the relationship between female director representation and environmental context.

\section{References}

Acker, J.: 1990, 'Hierarchies, Jobs, Bodies: A Theory of Gendered Organizations', Gender and Society 4(2), 139-148.

Adler, N. J.: 1997, 'Global Leadership: Women Leaders', Management International Review 37(1), 171-196.

Arken, D. E., S. L. Bellar and M. M. Helms: 2004, 'The Ultimate Glass Ceiling Revisited: The Presence of Women on Corporate Boards', Journal of Business Ethics 50, 177-185.

Beckman, C. M. and D. J. Phillips: 2005, 'Interorganizational Determinants of Promotion: Client Leadership and the Promotion of Women Attorneys', American Sociological Review 70, 678-701.
Bilimoria, D.: 2006, 'The Relationship Between Women Corporate Directors and Women Corporate Officers', Journal of Managerial Issues 18(1), 47-62.

Bilimoria, D. and S. Piderit: 1994, 'Board Committee Membership: Effects of Sex-Based Bias', Academy of Management Journal 37(6), 1453-1477.

Bilimoria, D. and J. Wheeler: 2000, 'Women Corporate Directors: Current Research and Future Directions', in M. Davidson and R. Burke (eds.), Women in Management: Current Research Issues (Paul Chapman, London), pp. 138-163.

Blau, F. D. and L. M. Kahn: 2003, 'Understanding International Differences in the Gender Pay Gap', Journal of Labor Economics 21(1), 106-144.

Burgess, Z. and P. Tharenou: 2002, 'Women Board Directors: Characteristics of the Few', Journal of Business Ethics 37(1), 39-49.

Burke, R. J.: 1997, 'Women on Corporate Boards of Directors: A Needed Resource', Journal of Business Ethics 16(9), 37-43.

Catalyst: 2004, 2003 Catalyst Census of Women Board Directors of the Fortune 1000. Catalyst, New York.

Center for Corporate Diversity: 2004, The Nordic 500 Index, Oslo.

Coffey, B. S. and J. Wang: 1998, 'Board Diversity and Managerial Control as Predictors of Corporate Social Performance', Journal of Business Ethics 17(14), 17951603.

Corporate Women Directors International (CWDI): 2004, Women Board Directors of the Fortune Global 200 Companies, Report (Corporate Women Directors International, Washington).

Dahlerup, D.: 1998, 'Using Quotas to Increase Women's Political Representation', in A. Karam (ed.), Women in Parliament: Beyond Numbers (IDEA, Stockholm), pp. 91-106.

Dahlerup, D. and L. Freidenvall: 2005, 'Quotas as a "Fast Track" to Equal Representation for Women', International Feminist Journal of Politics 7(1), 26-48.

Daily, C., T. Certo and D. Dalton: 1999, 'A Decade of Corporate Women: Some Progress in the Boardroom, None in the Executive Suite', Strategic Management Journal 20, 93-99.

Ding, D. and C. Charoenwong: 2004, 'Women on Board: Is It Boon or Bane?', Working Paper Presented at 2004 FMA European Conference, Zürich, June.

Eastough, K. and P. Miller: 2004, 'The Gender Wage Gap in Paid- and Self-Employment in Australia', Australian Economic Papers 43, 257-276.

Economist: 2006, Women and the World Economy: A Guide to Womenomics, April 12. 
European Commission: 2006, Women and Men in Decision-Making, Luxembourg: Employment and Social Affairs Directorate, http://www.europa.eu.int/comm/ employment_social/women_men_stats/out/measures _out438_en.htm, Accessed 25 April.

Fondas, N.: 1997, 'The Origins of Feminization', Academy of Management Review 22, 257-282.

Fryxell, G. E. and L. D. Lerner: 1989, 'Contrasting Corporate Profiles: Women and Minority Representation in Top Management Positions', Journal of Business Ethics 8(5), 341-352.

HESA: Higher Education Statistics Agency: 2003, First Destinations of Students Leaving Higher Education Institutions 2001/02.

Hillman, A. J., A. A. Canella and I. C. Harris: 2002, 'Women and Racial Minorities in the Boardroom: How do Directors Differ?', Journal of Management 28(6), 747-763.

Ibrahim, N. and J. Angelidis: 1995, 'The Corporate Social Responsiveness Orientation of Board Members: Are There Differences Between Inside and Outside Directors?', Journal of Business Ethics 14(5), 405-410.

International Labor Organization (ILO): 2004, Global Employment Trends for Women.

Izraeli, D.: 2000, 'Women Directors in Israel', in R. Burke and M. Mattis (eds.), Women on Corporate Boards of Directors: International Challenges and Opportunities (Kluwer, Dordrecht, The Netherlands), pp. 75-96.

Johnson, J. L., C. M. Daily and A. E. Ellstrand: 1996, 'Boards of Directors: A Review and Research Agenda', Journal of Management 22, 409-438.

Kesner, I.: 1988, 'Directors' Characteristics and Committee Membership: An Investigation of Type, Occupation, Tenure and Gender', Academy of Management Journal 31, 66-84.

Mattis, M. C.: 2000, 'Women Corporate Directors in the United States', in R. J. Burke and M. C. Mattis (eds.), Women on Corporate Boards of Directors: International Challenges and Opportunities (Kluwer, Dordrecht, The Netherlands), pp. 43-55.

McKinsey: 2005, Market Profile of Latin American Women.

Milliken, F. J. and L. L. Martins: 1996, 'Searching for Common Threads: Understanding the Multiple Effects of Diversity in Organizational Groups', Academy of Management Review 21(2), 402-433.

Oakley, J.: 2000, 'Gender-Based Barriers to Senior Management Positions: Understanding the Scarcity of Female CEOs', Journal of Business Ethics 27, 321-334.

Pollert, A.: 2005, 'Gender, Transformation and Employment in Central Eastern Europe', European Journal of Industrial Relations 11, 213-230.
Powell, G. N.: 1999, Handbook of Gender and Work (Sage, Thousand Oaks, CA).

Raaum, N. C.: 2005, 'Gender Equality and Political Representation: A Nordic Comparison', West European Politics 28(4), 872-897.

Rosenbaum, J. E.: 1989, Handbook of Career Theory (Cambridge University Press).

Rosener, J.: 1990, 'Ways Women Lead', Harvard Business Review, November-December, 119-125.

Singh, V., S. Kumra and S. Vinnicombe: 2002, 'Gender and Impression Management: Playing the Promotion Game', Journal of Business Ethics 37(1), 77-89.

Singh, V., S. Vinnicombe and S. Terjesen: 2007, 'Women Advancing Onto Corporate Boards', in S. Piderit and D. Bilimoria (eds.), Handbook of Women in Business and Management (Edward Elgar), pp. 304-329.

Smith, J.: 2000, 'Do Women Hold Other Women Back?', The Guardian, October 5. Accessible at: http://www. guardian.co.uk/tories2000/story/0,377628,00.html.

United Nations Development Programme (UNDP): 2006, Gender Empowerment Index.

United States Department of Labor (USDOL): 2005, Women in the Labor Force: A Datebook.

Williams, R. J.: 2003, 'Women on Corporate Boards of Directors and Their Influence on Corporate Philanthropy', Journal of Business Ethics 42(1), 1-10.

Women and Equality Unit (WEU): 2002, Key Indicators of Women's Position in Britain.

Siri Terjesen

Brisbane Graduate School of Business, Queensland University of Technology,

GPO Box 2434, 2 George St., Brisbane, QLD, 4001, Australia E-mail: s.terjesen@qut.edu.au

Siri Terjesen Entrepreneurship, Growth and Public Policy, Max Planck Institute of Economics, Kahlaische Straße 10, D-07745, Jena, Germany

Siri Terjesen

Texas Christian University, P.O. Box 298530, Fort Worth, TX 76129, U.S.A.

Val Singh

Cranfield School of Management, Cranfield University, Bedford, MK43 OAL, U.K. E-mail:v.singh@cranfield.ac.uk 